\title{
A Comparative Analysis of Extension Contacts and Extension Participation between Farmers using Drip Irrigation System and Conventional Irrigation System in Kinnow Cultivation of Punjab
}

\author{
Shachi Singh* and Rupinder Kaur \\ Department of Extension Education, P.A.U. Ludhiana, 141004, India \\ *Corresponding author
}

A B S T R A C T

\begin{tabular}{l} 
K e y w o r d s \\
$\begin{array}{l}\text { Extension Contacts, } \\
\text { Extension } \\
\text { Participation, } \\
\text { Conventional } \\
\text { irrigation system }\end{array}$ \\
\hline Article Info \\
\hline $\begin{array}{l}\text { Accepted: } \\
\text { 21 May } 2020 \\
\text { Available Online: } \\
\text { 10 June } 2020\end{array}$ \\
\hline
\end{tabular}

The present study was undertaken to analyze the extension contacts and participation in extension activities between the farmers using drip irrigation system and conventional irrigation system in kinnow cultivation of Punjab by collecting data from 200 farmers (100 each) in four districts of Punjab which were selected purposively i.e. Bathinda, Fazilka, Hoshiarpur and Sri Muktsar Sahib/ Faridkot. Data were collected by following interview schedule approach. Findings of the study revealed that KVK experts/FASC, scientists of PAU, Horticultural Development Officer, Agricultural Development Officer and technical staff of Soil Conservation Department were most contacted by both types of respondents. Kisan Mela, fruit show cum seminar, group meetings of citrus estates and farmer's training camps were the most preferred extension activities by the respondents using drip irrigation system as well as conventional irrigation system. Most of the respondents had medium level of extension contacts and extension participation.

\section{Introduction}

In this changing agricultural scenario and paradigm shift towards precision farming, drip irrigation has come off as the technology which is capable of providing more optimum utilization of water (Bhuriya et al., 2015). This system is associated with automatic irrigation scheduling technique, can save time, human labor and also minimize the wastage of water (Debnath and Patel, 2016). The purpose behind introduction of drip irrigation system is to save water and enhance the water use efficiency which is the need of the hour. However, besides saving water it also produces several other economic and social benefits to the society.

In major parts of the world, the need for obtainable water resources is swiftly surpassing the supply as well as the competition between the diverse sectors of the economy because scarcity of water is becoming a serious concern (Namara et al., 2015). 
The review of several studies which is being conducted in the past very articulately depicts that various socio-economic factors play a significant role in influencing the adoption of several new technologies pertaining to the field of agriculture. Extension contacts of respondents with SAUs, agricultural institutes and their participation in extension activities has a major role in diffusion of technological innovations. Keeping these things in mind the present study has been conducted to analyze the extension contacts and participation in extension activities between the farmers using drip irrigation system and conventional irrigation system in kinnow cultivation of Punjab.

\section{Materials and Methods}

The study was conducted in Punjab state. Four prominent districts in which kinnow is cultivated were selected purposively i.e. Bathinda, Fazilka, Hoshiarpur and Sri Muktsar Sahib/ Faridkot. From each district 25 farmers were selected randomly who had adopted drip irrigation system while 25 nonadopters were selected from the same area or the adjoining area of adopter farmers. Thus, 50 farmers from each district constituted a sample of 200 farmers for the study. Data were analyzed with the help of common statistical tools, appropriate to the nature of data and for the purpose of the study.

\section{Results and Discussion}

\section{Extension contacts}

Extension contacts referred to the frequency to which respondents made purposeful contacts with different extension agents for seeking information regarding drip irrigation system/conventional irrigation system in kinnow cultivation. Data in Table 1 indicate that in case of respondents using drip irrigation system, majority of them (62\%) frequently contacted scientists of PAU while 31 per cent respondents contacted them sometimes and rest 9 per cent respondents never contacted them. Little more than half $(52 \%)$ of the respondents frequently contacted KVK experts/FASC, 31 per cent respondents contacted them sometimes and remaining 7 per cent respondents did not contact them at all. Forty five per cent respondents frequently contacted Agricultural Development Officer for seeking information regarding drip irrigation system in kinnow cultivation while 35 per cent respondents contacted them sometimes and remaining 20 per cent never contacted them. Less than half i.e. 46 per cent respondents frequently contacted Horticultural Development Officer while 40 per cent respondents contacted them sometimes, 39 per cent respondents frequently contacted technical staff of Soil Conservation Department while little more than half $(52 \%)$ of the respondents contacted them sometimes.

In case of respondents using conventional irrigation system, it was found that 57 per cent of them frequently contacted scientists of PAU while 24 per cent respondents contacted them sometimes and rest 19 per cent respondents never contacted them. Little more than half $(53 \%)$ of the respondents frequently contacted KVK experts/FASC, 35 per cent respondents contacted them sometimes and remaining 12 per cent respondents did not contact them at all. Half of the respondents $(50 \%)$ frequently contacted Agricultural Development Officer while 32 per cent respondents contacted them sometimes and remaining 18 per cent never contacted them. Little more than half i.e. 51 per cent respondents frequently contacted Horticultural Development Officer while 34 per cent respondents contacted them sometimes for seeking information, 35 per cent respondents frequently contacted technical staff of Soil Conservation 
Department while 45 per cent of the respondents contacted them sometimes. It can be concluded that banks/cooperative society and experts of private organizations were least contacted while PAU scientists were most contacted by the respondents using drip irrigation as well as respondents using conventional irrigation system.

\section{Overall mean score and ranking of extension contacts}

From the data given in Table 2 it was observed that scientists of PAU were most contacted by the respondents with mean score of 2.55 followed by KVK experts/FASC (II rank), Horticultural Development Officer (III rank), technical staff of Soil Conservation Department (IV rank), Agricultural Development Officer (V rank), experts of private organizations (VI rank) and bank/cooperative society (VII rank) with mean score of $2.43,2.32,2.30,2.25,1.96$ and 1.79, respectively in case of respondents using drip irrigation system.

In case of respondents using conventional irrigation system, KVK experts/FASC were most contacted by the respondents with mean score of 2.41 followed by scientists of PAU (II rank), Horticultural Development Officer (III rank), Agricultural Development Officer (IV rank), technical staff of Soil Conservation Department (V rank), experts of private organizations (VI rank) and bank/co-operative society (VII rank) with mean score of 2.38, $2.36,2.32,2.15,1.96$ and 1.87 , respectively.

Based on the findings, it can be concluded that almost similar trend was observed in both types of respondents. From the data presented in Table 3 it can be concluded that little less than half i.e. 46 per cent of the respondents using drip irrigation system had medium level of extension contacts followed by high (43\%) and low (10\%) level, respectively. In case of respondents using conventional irrigation system it was found that 41 per cent of the respondents were having medium level of extension contacts followed by high $(31 \%)$ and low (28\%) level, respectively. These findings were in line with the results of Brar (2008) and Meenal et al., (2017).

\section{Participation in extension activities}

Data given in Table 4 shows that majority of the respondents (using drip irrigation system) i.e.72 per cent participated frequently in Kisan Mela while 23 per cent respondents had participated sometimes and only 5 per cent of them never participated in it.

Little more than half $(51 \%)$ of the respondents participated frequently in fruit show cum seminar while 38 per cent and 11 per cent respondents participated sometimes and never, respectively.

Forty eight per cent respondents participated in group meetings of citrus estates frequently while 40 per cent and 12 per cent participated sometimes and never, respectively. Less than half i.e. 46 per cent respondents participated in farmer's training camps while 38 per cent of them participated sometimes and rest 16 per cent never participated in it.

In case of respondents using conventional irrigation system, majority of the them i.e.76 per cent participated frequently in Kisan Mela while 15 per cent respondents had participated sometimes and only 9 per cent of them never participated in it.

Forty six per cent of the respondents participated frequently in group meetings of citrus estates while 35 per cent and 19 per cent respondents participated sometimes and never, respectively. 
Table.1 Distribution of respondents according to their Extension contacts $n=200$

\begin{tabular}{|c|c|c|c|c|c|c|c|}
\hline \multirow{2}{*}{$\begin{array}{c}\text { S. } \\
\text { No. }\end{array}$} & \multirow[t]{2}{*}{ Sources } & \multicolumn{3}{|c|}{ Drip $\left(n_{1}=100\right)$} & \multicolumn{3}{|c|}{ Conventional $\left(\mathbf{n}_{2}=\mathbf{1 0 0}\right)$} \\
\hline & & $\begin{array}{l}\text { Always } \\
\text { f }(\%)\end{array}$ & $\begin{array}{l}\text { Sometimes } \\
\text { f }(\%)\end{array}$ & $\begin{array}{l}\text { Never } \\
f(\%)\end{array}$ & $\begin{array}{c}\text { Always } \\
\text { f (\%) }\end{array}$ & $\begin{array}{l}\text { Sometimes } \\
\text { f }(\%)\end{array}$ & $\begin{array}{l}\text { Never } \\
\text { f }(\%)\end{array}$ \\
\hline I & \multicolumn{7}{|l|}{ PAU/University } \\
\hline i) & $\begin{array}{l}\text { KVK } \\
\text { experts/FASC }\end{array}$ & $52(52.00)$ & $39(39.00)$ & $9(9.00)$ & $53(53.00)$ & $35(35.00)$ & $12(12.00)$ \\
\hline ii) & Scientists of PAU & $62(62.00)$ & $31(31.00)$ & $7(7.00)$ & $57(57.00)$ & $24(24.00)$ & $19(19.00)$ \\
\hline II & \multicolumn{6}{|l|}{ State Department } & \\
\hline i) & $\begin{array}{l}\text { Agricultural } \\
\text { Development } \\
\text { Officer }\end{array}$ & $45(45.00)$ & $35(35.00)$ & $20(20.00)$ & $50(50.00)$ & $32(32.00)$ & $18(18.00)$ \\
\hline ii) & $\begin{array}{l}\text { Horticultural } \\
\text { Development } \\
\text { Officer }\end{array}$ & $46(46.00)$ & $40(40.00)$ & $14(14.00)$ & $51(51.00)$ & $34(34.00)$ & $15(15.00)$ \\
\hline iii) & $\begin{array}{l}\text { Technical staff of } \\
\text { Soil Conservation } \\
\text { Department }\end{array}$ & $39(39.00)$ & $52(52.00)$ & $9(9.00)$ & $35(3.005)$ & $45(45.00)$ & $20(20.00)$ \\
\hline III & \multicolumn{7}{|l|}{ Cooperatives } \\
\hline i) & $\begin{array}{l}\text { Bank/Co-operative } \\
\text { society }\end{array}$ & $21(21.00)$ & $37(37.00)$ & $42(42.00)$ & $25(25.00)$ & $37(37.00)$ & $38(38.00)$ \\
\hline IV & $\begin{array}{l}\text { Experts of Private } \\
\text { organizations }\end{array}$ & $26(28.00)$ & $44(43.00)$ & $30(29.00)$ & $29(29.00)$ & $38(38.00)$ & $33(33.00)$ \\
\hline
\end{tabular}

Table.2 Mean score and ranking of extension contacts by the respondents $n=200$

\begin{tabular}{|c|c|c|c|c|c|}
\hline \multirow[t]{2}{*}{ S. No. } & \multirow[t]{2}{*}{ Sources } & \multicolumn{2}{|c|}{ Drip $\left(n_{1}=100\right)$} & \multicolumn{2}{|c|}{$\begin{array}{c}\text { Conventional } \\
\left(\mathbf{n}_{2}=100\right)\end{array}$} \\
\hline & & $\begin{array}{l}\text { Mean } \\
\text { score }\end{array}$ & $\begin{array}{l}\text { Overall } \\
\text { ranking }\end{array}$ & $\begin{array}{l}\text { Mean } \\
\text { score }\end{array}$ & $\begin{array}{l}\text { Overall } \\
\text { ranking }\end{array}$ \\
\hline I & \multicolumn{5}{|l|}{ PAU/University } \\
\hline 1. & KVK experts/FASC & 2.43 & II & 2.41 & $\mathrm{I}$ \\
\hline 2. & Scientists of PAU & 2.55 & $\mathrm{I}$ & 2.38 & II \\
\hline II & \multicolumn{5}{|l|}{ State Department } \\
\hline 1. & $\begin{array}{l}\text { Agricultural Development } \\
\text { Officer }\end{array}$ & 2.25 & $\mathrm{~V}$ & 2.32 & IV \\
\hline 2. & $\begin{array}{l}\text { Horticultural Development } \\
\text { Officer }\end{array}$ & 2.32 & III & 2.36 & III \\
\hline 3. & $\begin{array}{l}\text { Technical staff of } \quad \text { Soil } \\
\text { Conservation Department }\end{array}$ & 2.30 & IV & 2.15 & V \\
\hline III & \multicolumn{5}{|l|}{ Cooperatives } \\
\hline 1. & Bank/Co-operative society & 1.79 & VII & 1.87 & VII \\
\hline IV & Experts of Private organizations & 1.96 & VI & 1.96 & VI \\
\hline
\end{tabular}


Table.3 Distribution of respondents according to their Extension Contacts

\begin{tabular}{|l|l|c|c|c|c|}
\hline \multicolumn{9}{|c|}{ DRIP $\left(\mathbf{n}_{\mathbf{1}}=\mathbf{1 0 0}\right)$} & \multicolumn{2}{c|}{ CONVENTIONAL $\left(\mathbf{n}_{2}=100\right)$} \\
\hline S.No. & $\begin{array}{l}\text { Extension } \\
\text { contacts }\end{array}$ & Frequency & Percentage & Frequency & Percentage \\
\hline 1. & Low (9-14) & 10 & 10.00 & 28 & 28.00 \\
\hline 2. & $\begin{array}{l}\text { Medium (15- } \\
\text { 20) }\end{array}$ & 47 & 44.00 & 41 & 41.00 \\
\hline 3. & High (21-26) & 43 & 43.00 & 31 & 31.00 \\
\hline
\end{tabular}

Table.4 Distribution of respondents according to their participation in extension activitiesn=200

\begin{tabular}{|c|c|c|c|c|c|c|c|}
\hline \multirow{2}{*}{$\begin{array}{l}\text { S. } \\
\text { No. }\end{array}$} & \multirow[t]{2}{*}{ Sources } & \multicolumn{3}{|c|}{$\operatorname{Drip}\left(n_{1}=100\right)$} & \multicolumn{3}{|c|}{ Conventional $\left(\mathrm{n}_{2}=\mathbf{1 0 0}\right)$} \\
\hline & & $\begin{array}{c}\text { Always } \\
\mathbf{f}(\%)\end{array}$ & $\begin{array}{l}\text { Sometimes } \\
\mathbf{f}(\%)\end{array}$ & $\begin{array}{l}\text { Never } \\
\mathbf{f}(\%)\end{array}$ & $\begin{array}{c}\text { Always } \\
\text { f(\%) }\end{array}$ & $\begin{array}{c}\text { Sometimes } \\
\mathbf{f}(\%)\end{array}$ & $\begin{array}{c}\text { Never } \\
\mathbf{f}(\%)\end{array}$ \\
\hline 1. & Field visits & $38(38.00)$ & $39(39.00)$ & $23(23.00)$ & $33(33.00)$ & $41(41.00)$ & $26(26.00)$ \\
\hline 2. & Kisan Mela & $72(72.00)$ & $23(23.00)$ & $5(5.00)$ & $76(76.00)$ & $15(15.00)$ & $9(9.00)$ \\
\hline 3. & Demonstrations & $42(42.00)$ & $33(33.00)$ & $25(25.00)$ & $38(38.00)$ & $29(29.00)$ & $33(33.00)$ \\
\hline 4. & Farmers' Training Camps & $46(46.00)$ & $38(38.00)$ & $16(16.00)$ & $40(40.00)$ & $31(31.00)$ & $29(29.00)$ \\
\hline 5. & Field days & 19(19.00) & $50(50.00)$ & $31(31.00)$ & $21(21.00)$ & $47(47.00)$ & $32(32.00)$ \\
\hline 6. & Exhibitions & $21(21.00)$ & $45945.00)$ & $34(34.00)$ & $24(24.00)$ & $40(40.00)$ & $36(36.00)$ \\
\hline 7. & Campaigns & $17(17.00)$ & $50(50.00)$ & $33(33.00)$ & $22(22.00)$ & $39(39.00)$ & $39(39.00)$ \\
\hline 8. & $\begin{array}{l}\text { Group meetings of } \\
\text { Citrus estates }\end{array}$ & $48(48.00)$ & $40(40.00)$ & $12(12.00)$ & $46(46.00)$ & $35(35.00)$ & $19(19.00)$ \\
\hline 9. & Fruit show cum seminar & $51(51.00)$ & $38(38.00)$ & $11(11.00)$ & $41(41.00)$ & $35(35.00)$ & $24(24.00)$ \\
\hline
\end{tabular}

Table.5 Overall mean score and ranking of extension activities by the respondents $n=200$

\begin{tabular}{|c|c|c|c|c|c|}
\hline \multirow[t]{2}{*}{ S. No. } & \multirow[t]{2}{*}{ Sources } & \multicolumn{2}{|c|}{ Drip $\left(n_{1}=100\right)$} & \multicolumn{2}{|c|}{$\begin{array}{c}\text { Conventional } \\
\left(\mathbf{n}_{2}=\mathbf{1 0 0}\right)\end{array}$} \\
\hline & & $\begin{array}{l}\text { Mean } \\
\text { score }\end{array}$ & $\begin{array}{l}\text { Overall } \\
\text { ranking }\end{array}$ & $\begin{array}{l}\text { Mean } \\
\text { score }\end{array}$ & $\begin{array}{l}\text { Overall } \\
\text { ranking }\end{array}$ \\
\hline 1. & Field visits & 2.15 & VI & 2.07 & $\mathrm{~V}$ \\
\hline 2. & Kisan Mela & 2.67 & I & 2.67 & $\mathrm{I}$ \\
\hline 3. & Demonstrations & 2.17 & V & 2.05 & VI \\
\hline 4. & Farmers' Training Camps & 2.30 & IV & 2.11 & IV \\
\hline 5. & Field days & 1.88 & VII & 1.89 & VII \\
\hline 6. & Exhibitions & 1.87 & VIII & 1.88 & VIII \\
\hline 7. & Campaigns & 1.84 & IX & 1.83 & IX \\
\hline 8. & $\begin{array}{l}\text { Group meetings of } \\
\text { Citrus estates }\end{array}$ & 2.36 & III & 2.27 & II \\
\hline 9. & Fruit show cum seminar & 2.40 & II & 2.17 & III \\
\hline
\end{tabular}


Table.6 Distribution of respondents according to their participation in extension activities $n=200$

\begin{tabular}{|l|l|c|c|c|c|}
\hline \multicolumn{9}{|c|}{ Drip $\left(\mathbf{n}_{\mathbf{1}}=\mathbf{1 0 0}\right)$} & \multicolumn{2}{c|}{ Conventional $\left(\mathbf{n}_{2}=100\right)$} \\
\hline S.No. & $\begin{array}{l}\text { Participation } \\
\text { in Extension } \\
\text { Activities }\end{array}$ & Frequency & Percentage & Frequency & Percentage \\
\hline 1. & Low (9-15) & 19 & 19.00 & 32 & 32.00 \\
\hline 2. & $\begin{array}{l}\text { Medium } \\
(16-22)\end{array}$ & 50 & 50.00 & 42 & 42.00 \\
\hline 3. & High (23-28) & 31 & 31.00 & 26 & 26.00 \\
\hline
\end{tabular}

Forty one per cent respondents participated in fruit show cum seminar frequently while 35 per cent and 24 per cent respondents participated sometimes and never, respectively. About 40 per cent respondents participated in farmers' training camps while 31 per cent of them participated sometimes and rest 29 per cent never participated in farmer's training camps.

Overall mean score and ranking of extension activities

Based on the mean score and ranking, the data from the Table 5 reveal that Kisan Mela was the most preferred extension activity by the respondents using drip irrigation system with a mean score of 2.67 followed by fruit show cum seminar (II rank), group meetings of citrus estates (III rank), farmers' training camps (IV rank) and demonstrations (V rank) with mean score of 2.40, 2.36, 2.30, and 2.17, respectively. It can be concluded that campaigns, exhibitions, field days and field visits were least preferred extension activities by the respondents with mean score of 1.84 , $1.87,1.88$ and 2.15 , respectively.

For the respondents using conventional irrigation system, Kisan Mela was the most preferred extension activity with mean score of 2.67 followed by group meetings of citrus estates (II rank), fruit show cum seminar (III rank), farmers' training camps (IV rank) and field visits (V rank) with a mean score of $2.27,2.17,2.11$ and 2.07, respectively. It can be concluded that campaigns, exhibitions, field days and demonstrations were least preferred extension activities by the respondents with a mean score of 1.83, 1.88, 1.89 and 2.05 , respectively.

From the data presented in Table 6 it can be concluded that more than half of the respondents using drip irrigation system i.e. 50 per cent had medium level of participation in extension activities followed by high (31 $\%)$ and low (19\%) level, respectively. These findings were in conformity with the findings of Patidar (2015). In case of respondents using conventional irrigation system it was found that less than half i.e. 42 per cent of the respondents were having medium level of participation in extension activities followed by low (32\%) and high (26\%) level, respectively.

It is an undeniable fact that extension contacts and participation of farmers in extension activities act as a catalyst for the farmers in adoption of new technologies. They help the farmers in acquiring more and more information, exchanging ideas and thoughts thereby changing their attitude, perception, increasing their knowledge and adoption level about new technologies. From the above findings it can be concluded that KVK experts/ FASC, scientists of PAU, 
Horticultural Development Officer, Agricultural Development Officer and technical staff of Soil Conservation Department were most contacted by both types of respondents. Kisan Mela, fruit show cum seminar, group meetings of citrus estates and farmer's training camps were the most preferred extension activities by the respondents using drip irrigation system as well as conventional irrigation system. But level of extension contacts and participation in extension activities was slightly better among respondents using drip irrigation system as compared to respondents using conventional irrigation system.

\section{References}

Bhuriya R, Choudhary S and Swarnakar V K (2015) Study of adoption behaviour of drip irrigation system on chilli crop in Barwani District of Madhya Pradesh, India. J Agri Vet Sci., 8: 12-14.

Brar K S (2008) An analytical study on knowledge, persuasion and adoption of farmers about recommended practices of Kinnow (Citrus delicosa X Citrus nobilis) cultivation in Rajasthan. Ph.D. dissertation. MPUAT, Udaipur, India.
Debnath M and Patel N (2016) Performance of a developed low cost microcontroller based automated drip irrigation system in kinnow crop. Retrieved from https: //www.krishisanskriti.org/vol_image/11 Sep201505092614.pdf on 1-3-2020.

Namara R E, Upadhyay B and Nagar R K (2005) Adoption and impacts of microirrigation technologies: empirical results from selected localities of Maharashtra and Gujarat states of India. Research Report.Pp-93.International Water Management Institute, Colombo, Sri Lanka.

Meena R R, Geanger $\mathrm{K}$ L, Meena B L, Bhatnagar P and Meena P L (2017) Anaysis of adoption and constraints perceived by Mandarin growers in Jhalawar district of Rajasthan. Int $J$ Curr Micro App Sci., 6: 1465-70.

Patidar J (2015) A study on knowledge and attitude of vegetable growers towards drip irrigation system in Sardarpur block of Dhar district Madhya Pradesh. M.Sc. Thesis, Rajmata Vijayaraje Scindia Krishi Vishwa Vidyalaya, Gwalior, India.

\section{How to cite this article:}

Shachi Singh and Rupinder Kaur. 2020. A Comparative Analysis of Extension Contacts and Extension Participation between Farmers using Drip Irrigation System and Conventional Irrigation System in Kinnow Cultivation of Punjab. Int.J.Curr.Microbiol.App.Sci. 9(06): 29562962. doi: https://doi.org/10.20546/ijcmas.2020.906.355 